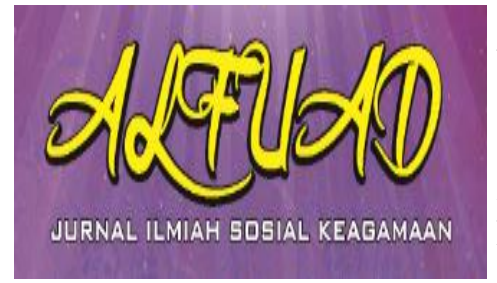

ALFUAD JOURNAL, 4 (1), 2020, (67-79)

(E-ISSN 2714-7606 P-ISSN 2614-4786 )

Available online at

http://ecampus.iainbatusangkar.ac.id/ojs/index.php/alfuad

\title{
ISLAMISASI ILMU SEBAGAI IDENTITAS KEAGAMAAN (TELAAH KRITIS SYED NAQUIB AL-ATTAS)
}

\section{Fahrudin*)}

Universitas Islam Negeri Sunan Kalijaga

Yogyakarta Indonesia

Email: fahru406@gmail.com

\section{Henki Desri Mulyadi}

Universitas Islam Negeri Sunan Kalijaga Yogyakarta Indonesia

Email: henkymulyady@gmail.com

\section{Ahmad Shofiyuddin Ichsan}

Institut Ilmu Al Qur'an An Nur Yogyakarta Indonesia

Email:

ahmad.shofiyuddin.ichsan@gmail.com

*) Corresponding Author

\begin{abstract}
This study aims to determine the Islamization of the science of Syed Naquib Al-Attas as a process of human liberation from magical, mythological, animistic, national-cultural traditions, and control of reason and language. The authors use the descriptive-analytic methods for library data that is relevant to the object of research. The results of this study indicate that the Islamization of the Syed Naquib Al-Attas science is an academic response in order to criticize the development of modern Western science which is considered to have fundamentally damaged the order of life. Al-Attas criticized the Western world view which had deified rational-empirical so that it is assumed that things that are supernatural and not visible to the human senses are something that cannot be trusted.
\end{abstract}

Keywords: Naquib Al-Attas, Islamization, Science

\section{PENDAHULUAN}

Kecanggihan teknologi sains modern yang (katanya) bersumber dari Barat sat ini tidak lepas dari ilmu pengetahuan yang bersumber dari Islam pada masa silam. Umat Islam pernah menjadi kiblat peradaban sekaligus pusat ilmu pengetahuan, bahkan selama tujuh abad lamanya Islam memimpin dunia. Sejarah itu, sampai saat ini belum ada yang dapat menggantikannya. Mengungkit sejarah emas Islam masa silam bukan berarti kita umat Islam kekinian hanya bisa berbangga diri atas sejarah emas tersebut. Namun kenyataanya, Islam memang pernah menciptakan peradaban yang maju dan menjunjung tinggi ilmu pengetahuan dan sains.
Hal demikian terbukti ketika para cendekiawan muslim tampil dengan sejuta keahlian dalam berbagai macam disiplin ilmu. Sebut saja dalam bidang hukum Islam (Fiqih), terdapat Imam Abu Hanifa, Imam Malik, Imam Syafi'i, dan Imam Ahmad Bin Hambal. Di bidang teologi, ada Al-Asy'ari, Al-Maturidi, dan AlJuba'i. Di bidang filsafat, kita kenal seperti Al Kindi, Al Farabi, Ibn Sina, dan Ibn Miskawai. Sedangkan di bidang tasawuf dan ilmu pengetahuan dan teknologi, ada nama seperti Dzun Nun Al Misri, Abu Yazid Al Busthami, dan Al Hallaj, Ibnu Al Haysam, Ibnu hayyan, al khawarizmi, Al Masudi dan Al-Razi (Nasution: 1975:13).

Kemunculan para ilmuan Islam dalam berbagai disiplin ilmu pada masa silam di 
atas menjadi bukti konkrit bahwa umat Islam pernah menciptakan sejarah dengan tradisi ilmiah. Lebih dari itu, umat Islam saat itu, sangatlah utuh dalam melihat ilmu pengetahuan artinya tidak ada cara berpikir yang memisahkan antara ilmu umum dan agama, sehingga kondisi ini menunjukan bahwa keterpaduan antara ilmu pengetahuan dan keimanan telah membentuk masyarakat Islamis (yang didasarkan pada al-Qur'an dan Hadist).

Sayangnya, kegemilangan umat Islam telah sampai pada titik kulminasi (puncak tertinggi), di mana pencapaian peradaban Islam tersebut pada saat ini hanya menjadi catatan sejarah. Hal ini disebabkan salah satunya adanya benturan internal muslim, seperti persoalan kepemimpinan (kekuasaan) dan diperkuat adanya serangan eksternal yang dilakukan kalangan di luar Islam. Jatuhnya kekuasaan Bagdad ditangan Hulagu Khan, misalnya, terjadi banyaknya para guru dan ilmuwan yang terbunuh, dan aktivitas keilmuan tercabik-cabik akibat serangan tersebut. Tidak hanya itu, kejadian kekalahan umat Islam dalam Perang Salib semakin memperburuk keadaan kaum muslim. Inilah realitas yang harus diterima sehingga kemunduran demi kemunduran semakin nyata, baik dalam kehidupan sosial, politik, ekonomi, pendidikan dan kebudayaan dalam dunia Islam.

Abad ke 18 terjadi sebuah revolusi industri di Inggris dan revolusi sosial politik di Prancis. Ini merupakan titik awal peralihan keadaan menuju peradaban modern. Gerakan Renaissance (pencerahan) di Eropa menjadi awal mulanya kejayaan Barat dalam mengembangkan teknologi. Bersamaan dengan kemunculan peradaban Barat tersebut, di tubuh umat Islam sendiri mengalami 'kemandegan'. Menurut
Marcel A. Boisar bahwa saat itu kondisi umat Islam sangat terbelakang, gerakan revitalisasi dan refungsionalisasi nilai-nilai tradisional lebih diutamakan dari pada melakukan riset-riset ilmiah yang berbasis sainstifik yang mengarah pada terciptannya teknologi. Sehingga umat Islam saat ini hanya menjadi 'konsumen' yang menikmati kemajuan yang terus disuguhkan oleh dunia Barat dengan berbagai kecanggihan teknologi dan keilmuannya.

Sejak terjadinya pencerahan di Eropa tersebut, maka sirkulasi kehidupan semakin berkembang dengan tensi yang cukup tinggi, yang notabene dunia Barat telah memprakarsai itu semua. Hal itu ditandai dengan berkembangnya ilmu-ilmu rasional yang dibangun atas dasar acuan pemikiran filsafat Barat yang di dalamnya terdapat paham sekularisme dan materialisme, sehingga konsep penafsiran dan makna ilmu itu sendiri tidak bisa terhindar dari pengaruh pemikiran Barat (Hasyim, 2005:29).

Modernisme Barat dengan kemajuan sains dan teknologi tersebut jika dianalisa lebih komprehensif hanya mampu memberikan nilai material pragmatis dengan mengorbankan nilai spiritual dan emosional dari manusia itu sendiri. Modernisme justru telah menjadi 'manusia predator'. Masyarakat modern Barat mengagungkan beberapa ideologinya seperti rasionalisme, antroposentrisme, sekularisme dan sains yang bebas nilai. Semua itu telah menempatkan manusia sebagai penguasa mutlak di muka bumi. Maka tidak mengherankan Syed Hossen Nasr mengatakan bahwa sains telah menjadi raja. Bahkan Sains dan teknologi telah menjadi kekuatan sistematis dalam menghegemoni paradigma kehidupan ilmiah. 
Teknologi modern yang dicapai Barat telah menarik nalar ilmuan dan intelektual seluruh umat manusia, dan paradigma epistemologi sains modern Barat tersebut telah menjadi superpower dan superior dalam menghegemoni kehidupan manusia. Hegemoni peradaban Barat yang didominasi oleh pandangan hidup saintifik telah menghilangkan kepekaan manusia pada rasa ketuhanan yang selama ini telah diyakini. Karen Amstrong dalam bukunya Sejarah Tuhan mengatakan bahwa sains tampaknya telah mengsampingkan Tuhan sebagai pencipta serta kultur ilmiah telah mendidik manusia untuk memusatkan perhatian hanya kepada dunia fisik material yang hadir di hadapannya. Pandangan seperti ini telah memberikan hasil pengetahuan yang kuat, tetapi salah satu akibatnya adalah manusia, sebagaimana yang terjadi, akan kehilangan kepekaan terhadap yang spiritual dan suci (Amstrong, 2013:19-29).

Atas dasar perkembangan ilmu pengetahuan yang kering akan nilai spiritual tersebut, maka lahirlah kesadaran dalam internal umat Islam. Beberapa respon dari pihak-pihak yang kontra atas kemajuan ilmu pengetahuan dianggap oleh kalangan ilmuan muslim terdapat paham sekularisme, utilitarianisme, dan materialism yang telah membuat pengetahuan modern menjadi kering dan kehilangan kesakralan serta nihil akan nilai-nilai ketauhidan, teologis, dan spiritual. Maka dari itu, tulisan ini akan menggungkapkan kritik dan respon ilmuwan muslim, yakni Syed Naquib AlAttas, terkait dengan upaya islamisasi ilmu pengetahuan yang dianggap sekuler tersebut.

\section{METODE}

Adapun metode penelitian kajian pustaka atau studi kepustakaan yaitu berisi teori teori yang relevan dengan masalah masalah penelitian. Pada bagian ini dilakukan pengkajian mengenai konsep dan teori yang digunakan berdasarkan literatur yang tersedia, terutama dari artikel-artikel yang dipublikasikan dalam berbagai jurnal ilmiah. Kajian pustaka berfungsi untuk membangun konsep atau teori yang menjadi dasar studi dalam penelitian. Kajian pustaka atau studi pustaka merupakan kegiatan yang diwajibkan dalam penelitian, khususnya penelitian akademik yang tujuan utamanya adalah mengembangkan aspek teoritis maupun aspek manfaat praktis. Sehingga dengan menggunakan metode penelitian ini penulis dapat dengan mudah menyelesaikan masalah yang hendak diteliti.

\section{HASIL DAN PEMBAHASAN}

\section{Latar Belakang dan Sumber Munculnya Pemikiran Barat Modern}

Dominasi gereja dalam sejarah perkembangan peradaban Barat berawal dari munculnya agama Kristen pada abad ke I sampai dengan XIV yang disebut sebagai abad pertengahan. Selanjutnya dibagi fase perkembanganya menjadi dua fase. Fase klasik dimulai dari abad 1 sampai abad ke VII dan abad pertengahan berlangsung dari abad ke VIII sampai abad ke XIV (Hanafi, 2000:40). Kemunculan agama Kristen merupakan peristiwa besar dalam sejarah peradaban Barat. Ajaranajaran Kristen yang cukup kuat berkaitan dengan adikodrati menjadi dasar bagi para penganutnya dalam melakukan tindakan.

Keyakinan yang sangat mengakar tersebut telah mendarah daging dalam 
sanubari para pengikutnya, sehingga cukup beralasan ketika dominasi Kristen mulai menyingkirkan peradaban Yunani-Romawi yang sebelumnya telah memprakarsai peradaban Barat saat itu. Dari sini, dimulainya perkembangan masyarakat Kristen, seni Kristen, kesusteraan Kristen, etika Kristen, serta teologi dan filsafat Kristen (Lukas, 1993:163).

Abad ke 15 dan 16 merupakan periode yang sangat krusial bagi Kristen Barat. Kristen Barat tidak hanya berhasil dalam mengejar ketertinggalan mereka sebelumnya, tetapi Kristen Barat bahkan nyaris menakluk seluruh kebudayaankebudayaan lainnya (Amstrong, 2013:387). Keunggulan Kristen pada abad pertengahan sangat besar, karena tidak ada institusi lain yang lebih unggul selain geraja Kristen (Lukas, 1993:163). Gereja adalah persekutuan semua umat manusia yang percaya terhadap doktrin Trinitas, serta mengakui posisi pendeta sebagai manifestasi Tuhan (yang menjadi penafsir kehendak Tuhan). Hampir semua orang saat itu dibaptis, karena memang kebanyakan mereka lahir dari rahim orang tua yang telah meyakini Yesus sebagai Tuhannya.

Institusi Gereja yang dipimpin oleh Paus mendeklasrasikan dirinya sebagai orang yang berhak memutuskan segala hal yang berkaitan dengan aturan-aturan kehidupan dunia maupun yang berkaitan dengan hubungannya terhadap Tuhan. Sifat otoritas yang dilegalkan kepada Paus mengindikasikan bahwa seluruh urusan yang berkaitan dengan surat wasiat, catatan sipil, pernikahan, dan seterusnya. Singkatnya, semua aspek kehidupan manusia termasuk juga kehidupan intelektual selalu di bawah otoritas Gereja. Tidak hanya itu, seluruh universitas telah didominasi dan diatur oleh sosok Paus, baik dalam isi pelajaran, maupun penunjukan tenaga pengajar di setiap universitas yang ada.

Anggapan bahwa pihak gereja merupakan hakim dan pengatur bagi kehidupan manusia telah berimplikasi pada adanya sikap penolakan dari pihak-pihak penantang terhadap keputusan Gereja. Hal itu karena di sana selalu dianggap benar walaupun merugikan masyarakat pada umumnya. Sehingga muncullah apa yang kita kenal dengan gerakan Renaissance (pencerahan) sebagai gerakan kelahiran kembali.

Upaya untuk mengembalikan kebudayaan lama atau dengan istilah kelahiran kembali adalah proses pencarian jalan baru sebagai langkah alternatif untuk keluar dari dominasi Kristen, usaha untuk mengembalikan kebudayaan itu diarahkan pada peradaban yang pernah mereka kenal yaitu peradaban Yunani-Romawi. Mereka menganggap peradaban klasik tersebut adalah ide yang cukup kaya akan kebudayaan sehingga pantas untuk menjadi sumber rujukan dan bahan pelajaran untuk diapresiasi.

Istilah kelahiran kembali, juga biasa dikenal dengan Auflarung yang mengandung makna munculnya kesadaran baru manusia yang telah lama dikungkung oleh sikap otoriter dan absolutis dari pihak Gereja. Kesadaran individual maupun kelompok ini kemudian tumbuh subur lantaran kesadaran penuh akan sebuah doktrin baru bahwa manusialah yang harus menjadi pusat dunianya, bukan sebaliknya. Renaissance juga meliputi keadaan di mana manusia merasa diri sebagai mahluk yang terasa berada dalam kelahiran kembali pada sumber-sumber yang murni bagi ilmu pengetahuan dan estetika. Hal yang sangat penting lagi pada masa renaissance adalah adanya gerakan yang 
menekankan pada otonomi dan kedaulatan manusia dalam berpikir, bereksplorasi, bereksperimen, dan mengembangkan berbagai macam ilmu pengetahuan modern.

Dalam perkembangannya, gerakan renaissance telah melahirkan suatu ideologi yang dikenal dengan filsafat humanisme yang menjunjung tinggi nilainilai dan kedudukan manusia sebagai individu yang merdeka. Humanisme sebagai gerakan intelektual berakar pada sejarah Yunani Kuno dan mulai muncul dan berkembang pada era renaissance. Kemunculan humanisme pada abad pertengahan ini sebagai sebuah gerakan reaksioner terhadap meluasnya belenggu kekuasaan dan lembaga-lembaga agama di Eropa. Kehidupan Eropa di abad pertengahan berada pada wacana teologis yang hegemonik, dengan model kekuasaan para pemimpin lembaga agama yang sangat doktriner dan otoriter. Sikap agamawan yang begitu absolut menjadikan hambatan perkembangan penemuanpenemuan para ilmuan, bahkan teori-teori baru yang bersebrangan dengan kekakuan dogma agama akan dianggap menyimpang atau sesat (Hadi, 2012). Atas dasar itulah, gerakan untuk keluar dari himpitan Gereja yang otoriter atas masyarakat Kristen pada umumnya semakin membuat sadar bahwa selama ini kebebasan berpikir meraka telah dirampas oleh Gereja yang semena-mena, sehingga mulai muncul inisiatif untuk bisa beraktivitas-berkreatifitas dan berpikir secara mendalam dan bebas yang sesuai dengan yang mereka inginkan.

Masa renaissance juga berarti masa yang menekankan pada otonomi dan kedaulatan manusia dalam berfikir, dalam mengadakan eksplorasi dan eksperimen, dalam mengembangkan seni sastra dan ilmu pengetahuan di Eropa. Ideologi yang berkembang pada masa ini dinamakan filsafat Humanisme, yang berarti sebagai bentuk filsafat eksistensialisme kolektif. Yakni adanya kesadaran diri yang merupakan bagian dari kolektif dan keputusan untuk turut menjadi bagian dari gerakan kolektif. Filsafat Humanisme dalam bentuk ideologi tersebar secara psikologis kepada orang-orang di masa Renaissance ini. Kesadaran yang muncul bukan aku adalah manusia, melainkan kita adalah manusia. Yang timbul adalah kesadaran bahwa kita adalah manusia, dan kita adalah yang utama. Mencoba melupakan organisasi di gereja dan keluar dalam pengabdian di dalamnya.

\section{Landasan Filosofis Ilmu Pengetahuan Barat Modern}

Akar dari pandangan Barat terhadap ilmu pengetahuan modern dapat dikatakan muncul bersamaan pada masa renaissance. Dalam perkembanganya, Rene Deskartes dan Isac Newton dianggap sebagai tokoh utama karena mengingat Descartes adalah tokoh yang paling besar pengaruhnya dalam formasi sains dan peradaban modern. Rene Deskartes dianggap sebagai bapak filsafat modern dengan ungkapannya yang fenomenal, "aku berpikir, maka aku ada" (Cagito Ergo Sum). Sedangan peran Newton terletak pada kemampuannya melakukan sintesis terhadap karya-karya Descartes. Galileo dan Kepler menentukan pemahaman tentang alam yang berlaku tidak hanya di dalam sains tapi juga kebudayaan Barat (Heriyanto, 2003:30-36).

Kemunculan Barat sangat didukung oleh ilmu pengetahuan yang berlandaskan pada aspek rasio semata. Dalam pandangan Deskartes, ia tidak saja mengukur suatu kebenaran menggunakan rasio, tetapi ia mengakui eksistensi seseorang hanya 
mereka yang menggunakan rasio sebagai asas tingkah lakunya (Husaini, 2013:243).

Pandangan Descartes tentang sumber ilmu adalah rasio. Pemahaman ini dikembangkan oleh filsuf lain, seperti Thomas Hobbes (1679), Benedict Spinoza (1677), Jhon Locke (1704), George Berkeley (1753), Francois-Marie Voltaire (1778), Jean-Jacques Rousseau (1778), David Hume (1776), Immanuel Kant (1804), George Friedrick Hegel (1831), Arthur Scopenhauer (1860), Soren Kierkegaard (1855), Edmund Husserl (1838), Henry Bergson (1941), Alfred North Whitehead (1947), Bertrand Russell (1970), Martin Heidegger (1976), Emilio Betti (1968), Hans-Geoger Gadamer, Jurgen Habermas, dan seterusnya (Armas, 2005:10).

Implikasi dari perkembangan ide ini adalah masifnya gerakan westernisasi ilmu pengetahuan yang menekankan pada rasio dan pancaindra. Adapun istilah Barat bukanlah tertuju pada letak geografis, tetapi lebih mengarah pada cerminan individu, kelompok, maupun masyarakat yang memiliki pandangan hidup yang saintifik (scientific wordview) dengan menanggalkan agama dan hal yang terkait metafisika dan teologi (Zakasyi, 2012:8687). Sedangkan ilmu pengetahuan modern adalah model pengkajian alam semesta yang dikembangkan oleh para filsuf dan ilmuan Barat sejak abad ketujuh belas. Untuk mengetahui landasan filosofis dari pandangan Barat ini, sangat penting untuk diketahui terkait dengan landasan ontologis, epistemologis, maupun landasa aksiologisnya, sehingga dengan itu dapat dipahami dan dianalisa secara komprehensif.

Dalam aspek ontologis, hal utama yang ingin dicapai oleh ilmu pengetahuan modern adalah realitas empiris (Sholihan,
2008:25). Realitas empiris adalah pandangan yang tolak ukur kebenarannya tertuju kepada sejauh mana ia dapat digunakan untuk kepentingan materil dan praktis, serta materialisme dan saintisme (Heriyanto, 2016). Sehingga hal-hal yang sifatnya metafisik dianggap ilusi dan tidak memiliki kebenaran.

Paham empirisme ini mengisolir dirinya hanya pada ranah-ranah yang dapat dilihat dan diraba oleh alat indrawi. Sedangkan yang diluar atau yang tidak dapat dilihat dengan indra dipandang tidak memiliki arti. Sebagaimana Immanuel Kant mengatakan bahwa pengetahuan adalah mungkin, sedangkan metafisika adalah tidak mungkin, karena tidak bersandarkan kepada panca indra.

Sejalan dengan pandangan ontologisnya, untuk mengetahui kebenaran, epistemologi Barat menggunakan metode keilmuan. Metode keilmuan ini merupakan gabungan antara metode rasionalistik dan empiristik, atau metode deduktif dan induktif. Formulasi paling pendek dari metode keilmuan ini adalah objek penelitian dapat dibuktikan secara logis dan ditunjukkan adanya bukti empiris (Sholihan, 2008:26). Artinya, masalah yang diteliti mempunyai obyek yang jelas (yang dalam hal ini adalah objek fisik). Ilmu yang objeknya tidak jelas-tidak memiliki fisik, maka dinilai tidak memiliki keobjektifan yang kuat. Seorang peneliti dikatakan tidak objektif ketika memasukkan unsur nilai dalam penelitiannya (Husaini, 2013:235).

Menurut Khairul Umam yang dikutip oleh Budi Handrianto mengatakan bahwa metode ilmiah yang mereka gunakan yaitu metode Logico-Hyphotetico-Verificative. Metode ini terlebih dahulu mencoba mengkaji pengetahuan dengan cara memikirkan sesuatu dengan aturan berpikir 
yang logis dan rasional dan bukan melalui aturan kepercayaan atau keyakinankeyakinan mistis. Berpikir secara logis tersebut dicoba untuk dapat ditarik hipotetsis (hyphotetico). Dari hipotesis itu, kemudian ilmu pengetahuan harus dapat dibuktikan secara empiris (verificative) (Husaini, 2013:236).

Landasan Epistemologi Barat yang hanya bertumpu pada hal-hal empiris yang dapat diterka oleh indrawi dan mengesampingkan sesuatu yang bersifat non-fisik (baca: metafisik) tersebut telah berimplikasi pada penolakan banyak hal, termasuk agama di dalamnya. Padahal pancaindra manusia dalam mengukur, mempertimbangkan, dan memutuskan sebuah kebenaran bukan saja memiliki keterbatasan melainkan juga berpotensi menyesatkan manusia.

Secara aksiologi, ilmu pengetahuan modern Barat tidak serta merta bisa digeneralisasi sebagai ilmu pengetahuan yang harus ditolak. Kerana bagaimanapun ilmu pengetahuan modern telah 'mengeluarkan' kehidupan manusia menuju kehidupan yang serba baru. Ilmu pengetahuan modern dengan kecanggihan teknologinya telah berkontribusi kepada umat manusia. Tetapi secara bersamaan, ilmu pengetahuan modern tersebut memberikan permasalahan baru, seperti ketimpangan sosial, kerusakan lingkungan, keterasingan diri manusia, membuat manusia bersifat individualistik, materialistik, hedonis, dan sulitnya menyeimbangkan dan menertibkan hubungan sosial antara satu individu dengan individu lain, antara masyarakat satu dengan yang lain.

Albert Enstein pernah mengatakan bahwa mengapa ilmu modern yang menghemat kerja dan yang membikin hidup lebih mudah ini realitasnya hanya membawa kebahagiaan sedikit bagi manusia? Dalam peperangan, kadang ilmu menyebabkan manusia saling meracuni satu sama lain. Dalam perdamaian, ia membuat hidup manusia dikejar waktu. Ilmu yang seharusnya membebaskan manusia dari pekerjaan yang melelahkan justru menjadikan budak-budak mesin (Enstein, 1992:248).

\section{Muhammad Naquib Al-Attas: Kritik terhadap Ilmu Pengetahuan Modern Barat}

Sebagaimana telah diuraikan dalam lembaran sebelumnya, bahwa keberadaan ilmu pengetahuan modern Barat telah melahirkan respon dari kalangan muslim. Di antara yang mengkritik epistemologi ilmu pengetahuan Barat ialah Syed Muhammad Naquib Al-Attas atau akrab disebut Al-Attas.

Al-Attas terkenal sebagai tokoh yang teguh pendirian dalam mengkritik pemikiran sarjana Barat yang sekuler. Menurutnya, ilmu pengetahuan Barat telah menciptakan krisis di tengah kehidupan umat manusia. Krisis ilmu pengetahuan modern Barat, menurut Al-Attas, disebabkan oleh konsep tentang realitas atau pandangan dunia yang melekat pada setiap ilmu, yang kemudian merambah ke persoalan epistemologi, seperti hubungan antara konsep dan realitas, masalah kebenaran, bahasa, dan yang menyakut masalah pengetahuan (Soleh, 2004:253).

Bagi Al-Attas, tantangan terbesar pada abad ini sesungguhnya adalah tantangan ilmu pengetahuan. Bukan tantangan karena kebodohan, tetapi dikarenakan adanya ilmu pengetahuan yang disusun dan disebarkan ke seluruh dunia oleh peradaban Barat. Pengetahuan yang sifat dasarnya menjadi permasalahan karena pengetahuan itu kehilangan tujuan 
yang sebenarnya karena disusun secara tidak adil. Sehingga ia justru menimbulkan kekacauan pada kehidupan manusia dari konteks kedamaian dan keadilan.

Lanjut Al-Attas, ilmu pengetahuan menganggap dirinya sesuai dengan kenyataan, padahal ilmu pengetahuan itu sendiri merupakan hasil dari kebingungan dan keragu-raguan. Ilmu pengetahuan telah mengangkat keragu-raguan dan dugaan pada tingkat ilmiah dalam metodologinya dan memandang keragu-raguan sebagai alat epistemologi yang paling valid dalam mecari kebenaran. Ilmu pengetahuan, selama masa pertama dalam sejarah telah membawa kekacauan tidak hanya pada manusia, tetapi juga pada tingkat kerajaan alam, yakni hewan, tumbuhan dan mineral (Al-Attas, 1979:19-20).

Ilmu pengetahuan modern yang diproyeksikan oleh Barat melalui pandangan hidup dibangun atas visi intelektual psikologis budaya dan peradaban Barat. Oleh karenanya, setidaknya terdapat lima faktor utama menurut Al-Attas yang selama ini menjiwai peradaban Barat.

Pertama, akal menjadi faktor utama untuk membimbing kehidupan manusia (Al-Attas, 1991:45). Bagi Al-Attas, menjadikan akal sebagai tumpuan untuk mengukur kebenaran serta menuntun kehidupan manusia merupakan kecacatan yang tidak disadari oleh peradaban Barat. Keterbatasan akal dalam menjangkau halhal yang gaib, mistis, dan yang tak tampak merupakan suatu kenyataan, sehingga sangatlah keliru jika akal manusia dijadikan pijakan dalam mengambil keputusan.

Kedua, bersikap dualistis terhadap kebenaran dan realitas (Al-Attas, 1981:197). Al-Attas mengatakan, antara Islam dan filsafat serta sains modern memang memiliki kesamaan, khususnya dalam konteks sumber dan metode ilmu. Hal ini menjadi kesatuan cara mengetahui secara nalar dan empiris, kombinasi realisme, idealisme, dan pragmatisme, sebagai fondasi kognitif bagi filsafat sains.

Namun bagaimanapun, menurut AlAttas, terdapat juga sejumlah perbedaan mendasar dalam pandangan hidup mengenai realitas akhir. Baginya, dalam Islam wahyu merupakan sumber ilmu pengetahuan realitas dan kebenaran akhir berkenaan dengan makhluk ciptaan dan pencipta. Sedangkan bagi Barat hanya bersandar pada realitas empiris-rasional yang hanya dapat dijangkau oleh indra, sehingga dalam hal ini menurut Al-Attas merupakan sebuah kekeliruan besar yang berujung pada penolakan terhadap yang bersifat supranatural.

Ketiga, memproyeksikan pandangan hidup sekuler. Dalam pandangan Barat bahwa tanpa wahyu, ilmu sains dianggap sebagai satu-satunya pengetahuan autentik. Kosong dari wahyu, ilmu pengetahuan hanya terkait dengan fenomena. Akibatnya, kesimpulan kepada fenomena akan selalu berubah sesuai dengan perkembangan zaman. Tanpa wahyu, realitas yang dipahami hanya terbatas kepada alam nyata.

Keempat, pengetahuan Barat modern bersikap skeptis dan meragukan segala sesuatu (Al-Attas,

1981:199). Kebingungan dan skeptisme telah menjadi alat epistemologi yang sah dalam keilmuan Barat. Hal demikian menyebabkan terjadinya perasaan tidak puas akan segala sesuatu yang dicari, sehingga pada akhirnya membangkitkan keinginan yang tak pernah terpuaskan karena keraguan selalu 'menghantui' sehingga setiap apa yang ditemukan tidak dapat membuat merasa puas. Epistemologi skeptisme yang 
dibangun oleh Barat ini tidak akan bisa mengantarkan pada kebenaran yang ingin dicapainya, dan memang pada kenyataannya tidak ada bukti bahwa keraguan dapat mengantarkan pada kebenaran.

Kelima, ilmu pengetahuan tidak netral. Ketidak netralan ilmu pengetahuan disebabkan oleh induksi pengetahuan dari hakekat dan esensi yang menyamar (atau dianggap sebagai ilmu pengetahuan). Bahkan secara keseluruhan, yang dianggap sebagai ilmu pengetahuan, sesungguhnya bukan ilmu pengetahuan itu sendiri, namun merupakan interpretasi. Yakni melalui prisma pandangan dunia, pandangan intelektual, dan persepsi psikologis dari peradaban yang melingkupi perumusan dan penyebaran. Dalam kaitan ini, apa yang dirumuskan dan disebarkan adalah pengetahuan yang telah dituangi dengan watak dan kepribadian peradaban yang ada, sehingga pengetahuan yang disajikan sebenarnya adalah pengetahuan semu.

Kelima kriteria di atas menjadi bahan kritikan Al-Attas terhadap epistemologi Barat yang mengesampingkan hal-hal yang bersifat supranatural, sebuah ilmu yang bersumber dari wahyu. Sehingga perbedaan antara pandangan umat Islam terhadap ilmu pengetahuan sangat terlihat jelas. Akhirnya, hal itu melahirkan kesimpulan yang berbeda pula. Membatasi sumber ilmu pengetahuan hanya dalam tataran empiris menjadikan ilmu pengetahuan yang dihasilkan oleh Barat dianggap oleh Al-Attas sebagai suatu problem yang harus cepat diatasi, sehingga respon islamisasi ilmu merupakan kerja intelektual yang sangat dibutuhkan di tengah kebingungan intelektual saat ini.

\section{Islamisasi Ilmu Sebagai Identitas Keislaman}

Secara historis, ide atau gagasan islamisasi ilmu pengetahuan muncul pada saat diselenggarakan Konferensi Dunia Pertama tentang Pendidikan Islam di Makkah pada tahun 1977. Konferensi yang diprakarsai oleh King Abdul Aziz University ini berhasil membahas 150 makalah yang ditulis oleh sarjana-sarjana dari 40 negara, dan merumuskan rekomendasi untuk pembenahan serta penyempurnaan sistem pendidikan Islam yang diselenggarakan oleh umat Islam seluruh dunia, salah satunya adalah gagasan yang terkait islamisasi ilmu pengetahuan. Gagasan ini antara lain dilontarkan oleh Syed Muhammad Naquib Al-Attas dalam makalahnya yang berjudul "Preliminary Thoughts on the Nature of Knowledge and the Definition and the Aims of Education dan Ismail R. Al-Faruqi dalam makalahnya "Islamicizing Social Science." (Muhaimin, 2003).

Mengikuti logika sederhana, islamisasi yang diartikan dengan mengislamkan ilmu mengandung pemahaman bahwa ilmu yang berkembang pesat selama ini, lebih-lebih di Barat, telah mengalami kesesatan sehingga perlu diislamkan. Suatu kenyataan, memang ada sebagian orang yang bersikap apriori setelah melihat fakta bahwa kemajuan ilmu pengetahuan tidak menjadikan Barat lebih beradab, bahkan Barat dinilai telah teralienasi oleh pengetahuan dan teknologinya. Ide islamisasi ilmu lahir seiring dengan berbagai keterpurukan dan ketimpangan yang mewarnai kehidupan umat manusia akibat terpisahnya ilmu dari agama, yakni berupa perkembangan ilmu pengetahuan dan teknologi yang semakin canggih Hal itu justru semakin mengabaikan nilai etis dan agama. Sebaliknya, agama yang tidak 
ditopang dengan ilmu pengetahuan disinyalir tidak layak 'jual' di tengah masyarakat maju yang ilmiah minded.

Secara substansial, proses islamisasi ilmu telah terjadi sejak masa Rasulullah Saw. Hal ini dapat kita lihat dari proses pengislaman yang dilakukan oleh Muhammad Saw terhadap masyarakat Arab pada saat itu. Melalui ajaran-ajaran Al-Qur'an sebagai sumber hukum Islam pertama, beliau merubah seluruh tatanan kehidupan Arab Jahiliyah kepada tatanan masyarakat Islam hanya dalam kurun waktu dua puluh tiga tahun. Dengan AlQur'an, Muhammad Saw. merubah pandangan hidup mereka tentang manusia, alam semesta, dan kehidupan dunia. Pengislaman ilmu ini diteruskan oleh para sahabat, tabiin dan ulama-ulama sehingga umat Islam mencapai kegemilangan dalam konteks ilmu pengetahuan.

Dengan pengetahuan Islam yang mendalam, mereka menyaring filsafat Yunani Kuno untuk disesuaikan dengan pemikiran Islam. Sebagai hasilnya, ada hal-hal dari filsafat Yunani Kuno yang diterima dan ditolak. Hanya saja, secara operasional, istilah islamisasi ilmu baru muncul dan dipopulerkan sebagai kerangka epistemologi oleh para pembaharu muslim pada tahun 70-an. Gagasan islamisasi ilmu di kalangan pemikir Muslim tersebut merupakan program epistemologi dalam rangka merekonstruksi peradaban Islam. Hal ini disebabkan adanya perbedaan yang fundamental antara pandangan keilmuan dalam Islam dengan peradaban Barat pada tataran ontologi dan epistemologinya.

Para cendekiawan yang terlibat dalam 'proyek' islamisasi ilmu, seperti Syed Muhammad Naquib Al-Attas, menyadari bahwa virus yang terkandung dalam ilmu pengetahuan Barat modern-sekuler merupakan tantangan yang paling besar bagi kaum Muslimin saat ini. Dalam pandangannya, peradaban Barat modern telah membuat ilmu menjadi problematis. Selain telah salah memahami makna ilmu, peradaban Barat juga telah menghilangkan maksud dan tujuan ilmu itu sendiri. Sekalipun peradaban Barat modern juga menghasilkan ilmu yang bermanfaat, namun peradaban tersebut juga telah menyebabkan kerusakan dalam kehidupan manusia.

Dalam pandangan Al-Attas, Westernisasi ilmu adalah hasil dari kebingungan dan skeptisisme. Ia telah mengangkat keraguan dan dugaan ke tahap metodologi ilmiah. Bukan hanya itu, ia juga telah menjadikan keraguan sebagai alat epistemologi yang sah dalam keilmuan. Menurutnya, Westernisasi ilmu tidak dibangun di atas wahyu dan kepercayaan agama, namun dibangun di atas tradisi budaya yang diperkuat dengan spekulasi filosofis yang terkait dengan kehidupan sekular yang memusatkan manusia sebagai makhluk rasional. Akibatnya, ilmu pengetahuan dan nilainilai etika dan moral yang diatur oleh rasio manusia terus menerus berubah. Al- Attas bercita-cita ingin menjadikan peradaban Islam kembali hidup dan memiliki pengaruh yang mewarnai peradaban global umat manusia. Karena itu, seluruh hidupnya ia persembahkan bagi upayaupaya revitalisasi peradaban Islam, agar nilai-nilai yang di masa lalu dapat membumi dan menjadi ikon kebanggaan umat Islam dapat menjelma dalam setiap lini kehidupan kaum muslim sekarang ini (Al-Attas, 1991:135).

Menurut Al-Attas, islamisasi ilmu adalah pembebasan manusia. Pertama dari tradisi takhayul, mitos, animisme, kebangsaan dan kebudayaan dan setelah itu pembebasan akal dan bahasa dari 
pengaruh sekularisme. Kedua, pembebasan jiwa manusia dari sikap tunduk kepada keperluan jasmaninya yang condong menzalimi dirinya sendiri, sebab sifat jasmaniahnya lebih condong untuk lalai terhadap fitrah manusia. Dengan itu, dapat mengganggu keharmonian dan kedamaian dalam dirinya yang pada gilirannya menjadi jahil tentang tujuan asalnya. Jadi, islamisasi bukanlah satu proses evolusi ( $a$ process of evolution) tetapi satu proses pengembalian kepada fitrah (original nature) (Al-Attas, 1991:44).

Menurut Al-Attas, ilmu pengetahuan tidak bersifat netral dan bebas nilai. Sehingga ketika ilmu berkembang di sebuah wilayah, ilmu tersebut dibentuk berdasarkan nilai-nilai budaya, ideologi, dan agama yang dianut oleh para pemikir dan ilmuwan di wilayah tersebut. Kemudian terjadilah apa yang disebut sebagai helenisasi ilmu, kristenisasi ilmu, islamisasi ilmu pada masa klasik Islam, kemudian westernisasi ilmu dalam bentuk sekularisasi oleh masyarakat Barat terhadap ilmu. Oleh karena itu, proses "islamisasi" oleh Mulyadhi Kartanegara (2003), adalah bentuk "naturalisasi" ilmu dalam rangka meminimalisir dampak negatif sains sekuler terhadap kepercayaan agama.

Supaya umat Islam terhindar dari prinsip-prinsip yang menjebak pada epistemologi ilmu pengetahuan Barat sekuler, maka ada empat poin yang harus diperhatikan seorang muslim dalam mengembangkan ilmu pengetahuan, yaitu: (1) Prinsip-prinsip utama Islam sebagai intisari peradaban Islam; (2) Pencapain sejarah kebudayaan Islam sebagai manifestasi ruang dan waktu dari prinsipprinsip utama Islam; (3) Bagaimana kebudayaan Islam dibandingkan dan dibedakan dengan kebudayaan lain dari sudut manifestasi dan intisari; Bagaimana kebudayaan Islam menjadi pilihan yang paling bermanfaat berkaitan dengan masalah-masalah pokok Islam dan non Islam di dunia saat ini.

Renungan ini sangat penting, karena jika diperhatikan secara komprehensif, pengalaman masa lampau serta rencana masa depan menuju satu arah perubahan yang diinginkan, maka harus dimulai dari rumusan sistem pendidikan yang paripurna. Jika proses penyerapan nilainilai tersebut sudah dilakukan, maka proses islamisasi ini akan membebaskan manusia dari tradisi magis, mitologis, animisme, tradisi budaya nasional yang bertentangan dengan Islam, dan kemudian dari kontrol sekuler kepada akal dan bahasanya.

Islamisasi akan membebaskan akal manusia dari keraguan (shakk), dugaan dan argumentasi kosong menuju keyakinan akan kebenaran mengenai realitas spiritual, dan materi. Islamisasi akan mengeluarkan penafsiran-penafsiran ilmu pengetahuan kontemporer dari ideologi, makna dan ungkapan sekuler (Daud, 2004:312).

Islamisasi pengetahuan yang ditawarkan tidak semata berupa pelabelan sains dengan ayat-ayat Al-Qur'an atau hadis yang dipandang relevan dengan penemuan ilmiah, tetapi beroperasi pada level epistemologis, di mana dilakukan "dekonstruksi" terhadap epistemologi Barat yang berkembang sekarang. Hal itu kemudian merekontruksi epistemologi alternatif dengan meramu secara kritis bahan-bahan yang ada pada tradisi intelektual muslim yang telah dibina selama lebih dari satu millenium oleh para filosof dan ilmuan klasik. Menurut Mulyadhi (2003), konstruksi ulang epistemologi ini akan meliputi pembahasan status ontologis obyek ilmu, klasifikasi, 
dan metodologi ilmu. Ilmu pengetahuan kontemporer bisa diislamkan dengan cara menafsirkan kembali fakta-fakta penemuannya menurut pandangan dunia (worldview) Islam yang termaktub dalam Al-Qur'an dan dengan menjuruskan kembali program-program penelitian sains dan teknologi. Bagi Al-Attas, proyek "Islamisasi Ilmu" adalah yang bersifat "Darūriyyat", karena jika tidak segera diislamkan, maka anomali yang timbul dari pengetahuan Barat yang sekularistik akan mengancam eksistensi agama, keturunan, dan harga diri umat Islam ke depannya.

\section{KESIMPULAN}

Ilmu pengetahuan yang berhasil diciptakan dan disebar luaskan oleh peradaban Barat modern saat ini harus diakui telah mampu menciptakan berbagai macam teknologi canggih dalam kehidupan umat manusia. Pandangan rasional-empiris dan skeptisme yang menjadi dasar pandangan peradaban Barat menjadi bahan kritikan dari berbagai kalangan, khususnya para ilmuwan muslim Maka dari itu, Al-Attas menganggap bahwa upaya islamisasi ilmu yang telah terlanjur disebar luaskan ini merupakan sesuatu hal yang bersifat "Daruriyyat", karena jika tidak segera dilakukan, akan menjadi anomali yang timbul yang mengancam eksistensi kehidupan Islam dan umatnya.

\section{DAFTAR PUSTAKA}

Al-Attas, S. N. (1991). The Concept Of Education In Islam Kuala Lumpur: ISTAC.

Al-Attas, S. N. (1981). Islam dan Sekularisme Terj. Karsijo. Bandung: Pustaka.
Al-Faruqi, I. R. (1984). Islamisasi Ilmu Pengetahuan, ter. Anas Mahyuddin. Bandung: Pustaka.

Amstrong, K. (2013). Sejarah Tuhan Bandung: Mizan.

Armas, A. (2005). Westernisasi Dan Islamisasi Ilmu. Majalah Islamia. Nomor 6 September.

Daud, W., \& Nor, W. M. (2004). Filsafat dan Praktik Pendidikan Islam Syed M. Naquib al-Attas, ter. Hamid Fahmy. Bandung: Mizan.

Hadi, S. (2012). Konsep Humanisme Yunani Kuno Dan Perkembanganya dalam Sejarah Pemikiran Filsafat. Jurnal Filsafat. Vol. 22, No. 2 Agustus.

Hanafi, H. (2000). Oksidentalisme: Sikap Kita Terhadap Tradisi Barat Jakarta: Paramadina.

Heriyanto, H. (2003). Paradigma Holistik. Jakarta: Teraju.

Husaini, A., dkk. (2013). Filsafat Ilmu: Perspektif Barat dan Islam. Depok: Gema Insani.

Kartanegara, M. (2003). Menyibak Tirai Kejahilan: Pengantar Epistemologi Islam. Bandung: Mizan.

Lukas, H. (1993). Sejarah Peradaban Barat. Yogyakarta: Tiara Wacana.

Muhaimin. (2003). Arah Baru Pengembangan Pendidikan Islam, Pemberdayaan, Pengembangan kurikulum, hingga Redifinisi Islamisasi Pengetahuan. Bandung: Nuansa.

Nasution, H. (1975). Pembaharuan dalam Islam: Sejarah Pemikiran dan Gerakan. Jakarta: Bulan Bintang.

Soleh, A. K. (2004). Wacana Baru Filsafat Islam Yogyakarta: Pustaka Pelajar.

Suriasumantri, J. S. (1992). Ilmu dalam Perspektif. Jakarta: Yayasan Obor Indonesia. 
Fahrudin, Henki Desri Mulyadi, Ahmad Shofiyuddin Ichsan: Islamisasi Ilmu sebagai ...

Solihan. (2008). Modernitas, Post Modernitas, Agama. Semarang: Walisongo Press.

Zarkasyi, H. F. (2012). Misykat: Refleksi tentang Westernisasi, Liberalisasi dan Islam. Jakarta: INSIST dan MIUMI. 